\title{
Ruslands nabopolitik: hovmod og fald
}

Anders Åslund

Ruslands udenrigspolitik og energipolitik skaber usikkerhed på energimarkedet i Europa og skræmmer nabolandene væk. I Kreml er magten overtaget af en gruppe tidligere efterretningsfolk, hvis vigtigste mål er at blive stenrige, og som ikke tåler opposition. Vesten må træde i karakter og holde Rusland fast på OSCE-forpligtelserne

Vladimir Putin sagde, hvad han mente, da han kastede sig ud i en antiamerikansk tirade i München i februar og anklagede USA for at have "overskredet sine nationale grænser i enhver henseende: på det $\varnothing$ konomiske, det politiske og det humanitære område påtvinger det andre stater sin politik. Hvem synes vel om det?” På baggrund af USA's vanskeligheder i Irak er det naturligt, at den russiske præsident havde det godt med den amerikanske svaghed. Men det var lige så interessant, hvad han fik sagt om sin indenrigspolitik.

I løbet af de sidste to årtier har Rusland gennemgået en enorm forandring. Den reale vækstrate i øko- nomien har været syv procent om året siden 1999, og denne vækstrate forventes at fortsætte. I de sidste syv år har Rusland haft et overskud på betalingsbalancens løbende poster på ti procent af BNI, og det har opbygget rigelige valutareserver. De sidste to år har overskuddet på statsbudgettet været mere end syv procent af BNI. Det mest forbløffende tal er, at BNI i løbende priser (dollars) er femdoblet i løbet af de samme syv år fra 200 mia. i 1999 til 1.000 mia. sidste år.

Tre faktorer kan forklare denne glimrende økonomiske udvikling. For det første har Rusland fået skabt en kritisk masse af private virksom- 
heder og markeder. For det andet virkede det finansielle sammenbrud i 1998 som en renselse, der gjorde russerne ekstremt ortodokse i deres finans- og pengepolitik. For det tredje har landet profiteret stort på de høje internationale olie- og gaspriser.

\section{Ikke Putins fortjeneste}

Den tydelige pointe er, at Vladimir Putin overhovedet ikke har bidraget til denne økonomiske succes. Han er blot begunstiget af omstændigheder, som andre har skabt.

På det økonomiske område har Putin dog gjort to gode ting. Han har fastholdt en meget stærk makro$\varnothing$ konomisk politik, og han har fokuseret på økonomisk vækst. I sine første tre år videreførte han vigtige markedsreformer, som præsident Boris Jeltsin havde indledt; men i de seneste fire år har hans overordnede strukturpolitik været renationalisering. Siden 2003 har statsdominerede selskaber som Gazprom (naturgas), Rosneft (olie), Vnesjtorgbank (udenrigshandelsbank) og Rosoboronexport (våbeneksport) opkøbt mange af Ruslands bedste og mest værdifulde private selskaber, ikke altid med disses gode vilje. Enten er prisen påfaldende lav, og det er tydeligt, at salget ikke er helt frivilligt, eller prisen er påfaldende $h ø j$ og giver anledning til mistanke om returkommission i en størrelsesorden på en halv snes procent.
Denne artikels påstand er, at nøglen til at forstå Ruslands udenrigspolitik er, at den er domineret af kommercielle interesser. Som Dmitri Trenin på Carnegie Moscow Center formulerer det: "Ruslands business er business." Præsident Calvin Coolidge sagde engang det samme om USA. Putins nærmeste støtter, overvejende hans KGB-kammerater fra Sankt Petersborg, er bestyrelsesformænd i Ruslands største statsdominerede selskaber. Denne nye elite er nu travlt optaget af at berige sig selv.

Efter denne fortolkning tjener det genopstandne autoritære styre i Rusland primært til at skjule deres korruption og til at lette dem vejen til rigdom.

Korruptionen i Rusland var slem før; men under præsident Putin er den blevet virkelig gennemgribende. Alle institutioner, der måler korruption, har konstateret en væsentlig stigning de sidste to år. Den russiske afdeling af Transparency International har rapporteret, at viceministerposter handles for otte-ti millioner dollars, mens udnævnelser til provinsguvernør eller minister koster flere gange så meget, afhængigt af hvor store indkomster den pågældende post kan kaste af sig.

Præsident Putins nære ven fra Sankt Petersborg kommunikationsminister Leonid Reiman tabte en sag ved en forligsret i Zürich. Retten fastslog, at Reiman i løbet af sin tid som statsembedsmand havde samlet sig russiske telekommunikationsakti- 
ver til en værdi af mere end én milliard dollars i strid med russisk lov. Reiman har vedholdende afvist disse beskyldninger, og disse oplysninger, som ville være en kæmpeskandale i ethvert åbent samfund blev ikke offentliggjort i landsdækkende russiske medier. Reiman sidder stadig i sit job med Putins klare støtte. Det er svært at frigøre sig fra det indtryk, at topfolkenes berigelse er et vigtigt mål for Putin-regimet.

Putin-regimet er højst sandsynligt verdens mest grådigt korrupte nogensinde.

\section{Et autoritært system}

Set i bakspejlet er det tydeligt, at det fra starten var Putins hensigt at etablere et autoritært system. Freedom House har med rette ændret sin betegnelse for Rusland fra 'delvis frit' til 'ikke frit'. Folk i almindelighed er overbevist om, at Putin har skabt stabilitet i landet; men drabstallet er faktisk steget signifikant siden Jeltsins tid. Forskellen i dag er, at regeringen skjuler den slags dårlige nyheder, om end statistikkerne stadig bliver offentliggjort.

Samtidig med, at Putin har fremhævet sit ønske om at styrke demokrati og retsorden i Rusland, har han gradvis og systematisk afviklet begge dele. Stort set hvert eneste skridt har han retfærdiggjort med en eller anden juridisk undskyldning; men de er alle gået i samme retning. Berkeley-politologen Ste- phen Fish har leveret fremragende dokumentation og analyse af denne proces i sin bog Demokratiet afsporet $i$ Rusland.

Statslige selskaber eller private forretningsfolk tæt på Putin har opkøbt det ene medie efter det andet ved mere eller mindre frivillige ordninger med det resultat, at medierne er blevet dummere og ubetingede Putin-støtter.

Valgene er blevet manipuleret med mindre finesse. Den ene kandidat efter den anden er blev strøget af stemmesedlerne med de mest latterlige formelle begrundelser. Nye partier kan ikke blive officielt registreret. I de allerede eksisterende partier opkøber Kreml delegerede for at få opstillet sine egne kandidater. Trusler bruges mere og mere, og hvert år bliver der dræbt nogle journalister. Mordet på den Putin-kritiske og enestående modige Anna Politkovskaja kom ikke som nogen overraskelse.

Den nye lov om ngo'er giver regeringen mulighed for at lukke hvilken som helst af dem når som helst. Om ikke andet kan autoriteterne altid finde fejl i deres bogføring. Forretningsfolk er klogt nok bange for at give økonomisk støtte til uafhængige organisationer og partier. I stedet donerer de til Kreml og den ortodoks kirke. Inden for det seneste år har regeringen ved lov udtrykkeligt forbudt kritik af embedsmænd og politikere, og demonstrationer havde man allerede forbudt. 
Arrestationen af direktøren for og hovedaktionæren i Yukos olieselskabet i oktober 2003 markerede overgangen til rent autoritært styre. Mikhail Khodorkovsky fik otte års fængsel på stort set falske anklager, og Yukos med en værdi på 45 mia. dollars blev konfiskeret ved ulovlig beskatning. Oligarkerne fik en lærestreg om at støtte Kreml, og Kreml tjente tykt på konfiskeringen via det statslige olieselskab Rosneft.

\section{Tjetjeniens rolle}

I disse antidemokratiske bestræbelser har krigen i Tjetjenien været til stor hjælp. Putin opbyggede sin popularitet ved at starte den anden

Tjetjenienskrig, og tjetjenske terrorhandlinger retfærdiggør alle tænkelige autoritære tiltag fra det russiske sikkerhedspolitis side. Den Europæiske Menneskerettighedsdomstol i Strasbourg har for nylig kendt det russiske politi i Tjetjenien skyldigt i at udøve tortur, og vakt Putins vrede. For tre år siden blev tre russiske GRU-agenter taget på fersk gerning, da de myrdede en tidligere tjetjensk præsident i Qatar. Den russiske regering pressede Qatar til en hurtig udlevering til Rusland, hvor de blev belønnet. Sidste år legaliserede det russiske parlament mord på terrorister, og kort tid senere blev den tidligere KGB-agent Aleksandr Litvinenko myrdet på eksotisk vis med polonium i London. Putins regime er dog mere tsaristisk end sovjetisk, og det er indtil videre autoritært på en forholdsvis mild måde. Spørgsmålet er, hvor langt han vil gå for at styrke sit diktatur.

\section{Dårligere forhold til Vesten}

Forholdet mellem Vesten og Rusland er blevet alvorligt forringet under Putin. I hans første valgperiode begik vestlige ledere den forståelige fejl at behandle Putin som Jeltsin. De troede, at Putin delte deres grundlæggende værdier, men bare manglede indsigt og derfor havde brug for venlig vejledning. Det modsatte var tilfældet. Som tidligere efterretningsagent kendte Putin Vesten ganske godt; men han var autoritær.

Putin fokuserede på personer og charmerede visse vestlige ledere den daværende tyske kansler Gerhard Schröder, den daværende italienske statsminister Berlusconi, den snart forhenværende franske præsident Jacques Chirac og, mest bemærkelsesværdigt, præsident

George W. Bush. Midt under Yukosaffæren i september 2003 sagde Bush: "Jeg respekterer Putins vision for Rusland: Et land der har fred inden for sine grænser, med sine naboer og med verden, et land hvor demokratiet, friheden og retssikkerheden blomstrer." Bogstavelig talt hvert eneste element i denne lange sætning er forkert.

Men Rusland var imødekommende over for USA i krigen mod 
Afghanistan, og Bush vil ikke gå med til, at han skulle have sagt noget som helst forkert. Den 1. februar blev han citeret i Wall Street Journal: "Vladimir Putin har holdt alt, hvad han har lovet mig." Tja, så kan han ikke have lovet ret meget. Putin gjorde gengæld i sin antiamerikanske tale i München: "Jeg betragter USA's præsident som min ven. Han er et fint menneske." Han kunne lige så godt have sagt: "Han er en nyttig idiot." Et eksempel herpå er, at USA sidste år gik med til at ophæve sin embargo mod den russiske flyfabrik Sukhoi på grund af dens leverancer til Iran. Kreml gav øjeblikkelig udtryk for sin anerkendelse af Washingtons svaghed ved at levere luftforsvarsmissiler til Iran.

I en tale i Vilnius i maj 2006 kritiserede vicepræsident Dick Cheney Rusland for at undertrykke demokratiet, for manglende sikkerhed i det post-sovjetiske område og for manglende energisikkerhed; men hans tale var en enlig svale.

På G-8 topmødet i Sankt Petersborg i juli 2006 fornærmede Putin Bush offentligt under en pressekonference. Bush rejste tidligt hjem, men uden at have svaret igen offentligt. Hvis man ikke tør sige et muk offentligt, vil man næppe have megen indflydelse på Ruslands udenrigspolitik. USA's Ruslandspolitik er lille, men uden styring. Hvis man ikke optræder seriøst, vil man med sikkerhed ikke blive taget alvorligt af russerne.
Med endnu større held har Putin splittet den Europæiske Union ved at pleje dens sydlige medlemmer Frankrig, Grækenland, Italien og Spanien - og træde på Polen og Estland, Letland og Litauen, som har knyttet sig tæt til USA. I Moskva kaldes disse fire lande den 'aggressive nye minoritet' i EU. EU er ikke i stand til at formulere en fælles Ruslandspolitik eller energipolitik, hvilket passer Kreml perfekt.

\section{Frastødte naboer}

Ruslands nabolag er noget ganske andet, for her finder man politiske ledere, som ved, hvordan man forholder sig til Moskva. Samtidig har Rusland vist sig mest udenrigspolitisk aggressiv mod sit nabolag af tidligere sovjetrepublikker. Rusland har trådt så brutalt på dem - med pludselige prisstigninger, olie- og gasstop, transportblokader, handelsstop, klapjagt på immigranter - at de alle styrter mod udgangene og søger tættere samarbejde med NATO og EU eller arbejder på at bygge nye rørledninger uden om Rusland. Ruslands rolle i regionen er aftagende trods dets voksende olie- og gasfyrede økonomiske velstand. Som det for nylig blev formuleret af den nationalistiske, intellektuelle Stanislav Belkovsky, direktør for Instituttet for National Strategi i Moskva: "I 2006 holdt Rusland op med at være en regional stormagt."

Det er således lykkedes Rusland at 
spænde ben for sig selv, for nu kan ikke nok så mange forsikringer fjerne Europas usikkerhed med hensyn til, om Rusland er en pålidelig energileverandør. Og i det post-sovjetiske rum tager både venner og fjender afstand, fordi de finder Putins regime for upålideligt og for ubehageligt. Det et således næppe rigtigt, som mange mener, at Rusland hengiver sig til nyimperialisme, eftersom Ruslands udenrigspolitik over for de tidligere sovjetrepublikker øjensynlig kun støder dem bort.

Intet post-sovjetisk land tør længere stole på Rusland. Alle som kan, vender sig væk og mindsker deres afhængighed. De omfattende embargoer mod Georgien og Moldova har gjort dem til Ruslands modstandere, skønt den økonomiske skade, de har lidt, har været overraskende ringe. Aserbajdsjan er holdt op med at handle olie og gas med Rusland, og Georgien gør sig klar til at stoppe importen af Russisk gas. GUAM det rudimentære sikkerhedssamarbejde mellem Georgien, Ukraine, Aserbajdsjan og Moldova - er ved at skulle spille en virkelig rolle. Ruslands bølleoptræden er dog hverken vedholdende eller konsekvent. Det trak faktisk sin garnison i Tbilisi tilbage efter mere end to hundrede år uden at få noget til gengæld. Østpå har Kasakhstan valgt at bygge flere rørledninger uden for Ruslands rækkevidde.

Rusland rammer ikke bare sine fjender, men også sine venner i det post-sovjetiske område. Sidste år opmuntrede Rusland de autonome territorier Transdnestr og Sydossetien til at afholde folkeafstemning om uafhængighed fra hhv. Moldova og Georgien. Men efter at deres ledere havde fulgt opfordringen og opnået de ønskede resultater, anerkendte Moskva ikke deres uafhængighed, men lod dem hænge og dingle.

Og Rusland gjorde intet for at hjælpe det venligtsindede Armenien, da det blev hårdt ramt af Ruslands embargo mod deres fælles naboland Georgien. Men det mest påfaldende er måske forholdet til Hviderusland, hvor Rusland har holdt Aleksander Lukasjenkos diktatur oppe i årevis med olie- og gassubsidier svarende til en tiendedel af Hvideruslands BNP. Kremls overraskende beslutning om at stoppe disse subsidier fra 2006 begravede effektivt den længe lovede union mellem Rusland og Hviderusland. Selv Lukasjenko henvender sig nu til Vesten. Alt andet end Rusland!

Fanget i vækstfetichisme vender Putin sig i stedet til Indien og i særdeleshed Kina, skønt Kina potentielt udgør den største strategiske trussel mod Rusland med dets store, tyndt befolkede områder i Sibirien og Fjernøsten.

\section{Putin igen igen?}

Mærkeligt nok fastholder Putin, som er hovedarkitekten bag hele denne autoritære udvikling, at han 
ønsker at trække sig i marts 2008, fordi forfatningen ikke tillader ham at sidde længere. Normalt trækker diktatorer sig ikke tilbage. Hvis $\mathrm{Pu}-$ tin virkelig mente det alvorligt, skulle han have forbedret demokratiet og retssikkerheden for at sikre sig immunitet ligesom Jeltsin. Enten har Putin uforvarende bragt sig i en situation, hvor han bliver nødt til at acceptere en tredje valgperiode Kreml har allerede startet en 'folkelig' kampagne for at overtale ham, eller også har det hele tiden været planen.

Hans regimes styrke skal dog ikke overdrives. Det er kendetegnet ved ekstrem overcentralisering. Lidt overdrevet kan man sige, at alle vigtige politiske beslutninger træffes af en lille håndfuld mænd $\mathrm{i}$ Kreml.

Alle mellemniveauerne er udvandet. De herskende kan umuligt få tilstrækkelig information til deres beslutninger. Politisk analyse er i det store og hele stoppet og negativt feedback er forbudt.

Det afgørende spørgsmål er, hvordan Putin-regimet vil slutte. For første gang i russisk historie har det hemmelige politi fuld kontrol, hele vejen til toppen. En lukket kreds af Putins venner fra hans tid i KGB i Sankt Petersborg regerer i Kreml. Anført af Igor Setjin, Putins nærmeste kollega, styrer de stort set alle sikkerhedsorganerne. Der spekuleres meget over, om selv Putin overhovedet kan sætte dem stolen for døren. Den mest nærliggende histo- riske parallel til Setjingruppen er den gruppe, som blev styret af chefen for Stalins sikkerhedspoliti, Lavrentii Beria, om end der er en stor forskel: Til forskel fra Putin var Stalin ikke sikkerhedsapparatets mand; det var ham, der manipulerede sikkerhedsapparatet efter sine egne behov. Og så er der en anden stor forskel: Setjin gruppen er kun interesseret $i$ at samle sig enorm rigdom, ikke $i$ at kontrollere russernes tilværelse. Det er derfor gruppen er foruroliget over det kommende præsidentvalg i 2008, og Moskva summer af rygter om, at Putin vil finde en udvej for at blive siddende.

\section{Vesten må træde i karakter}

\section{I betragtning af, hvad der står på} spil, kan Vesten ikke længere nøjes med at se til fra sidelinjen. Seks års eftergivenhed har ikke gjort andet end at opmuntre Ruslands antivestlige politik. Vesten kunne tage ved lære af Mikheil Saakashvili, Georgiens præsident, og nok tale mildt til Rusland, men med en stor stok i hånden. Sandsynligvis var Estland og Georgien de lande, der havde mest held med ruslandspolitikken sidste år, og det var nok dem, der optrådte med størst fasthed. Russerne sætter pris på styrke og mod.

Præsident Ronald Reagan vidste, hvor vigtigt det var at sige sandheden højt og klart. Når vestlige ledere nu fedter for Putin med falske komplimenter, vækker de kun foragt i 
Kreml. Vicepræsident Cheneys tale i Vilnius var en tiltrængt afvigelse, som Kreml blev rasende over. Det er på tide, at Vesten følger den op.

Vesten overtalte den sovjetiske leder Leonid Bresjnev til at ratificere Helsingfors-aftalerne i 1975 om menneskerettigheder og frie og fair valg. De spillede en vigtig rolle i undermineringen af det sovjetiske diktatur. USA skulle tage dem op igen nu, da Rusland nærmer sig en ny runde parlaments- og præsidentvalg, hvor det nu ser ud til, at hver eneste regel i bogen vil blive brudt.

I München reserverede Putin netop sit groveste overfald til OSCE (Organisationen for Sikkerhed og Samarbejde i Europa), som blev grundlagt på Helsingfors-aftalerne og er den internationale organisation, der overvåger valg. Putin beskyldte ligesom Bresjnev OSCE for at "blande sig i andre landes interne forhold"; men Helsingfors-aftalerne gjorde netop demokratiet til et internationalt anliggende. Putin og hans kumpaner vil næppe kunne lide det; men i betragtning af sammenhængen mellem Ruslands politik på hjemmefronten og dets udenrigspolitiske opførsel, er det vigtigt, at Vesten holder Rusland fast på OSCE-forpligtelserne.

Anders Åslund er specialist $i$ den postkommunistiske økonomiske transformation med mere end 30 års erfaring på området og er siden januar 2006 senior fellow på Peterson Institute for International Economics, Washington, DC. Hans bog "How Capitalism Was Built" kommer på Cambridge University Press til efteråret.

Oversat fra engelsk af Klaus Carsten Pedersen. 